\title{
Vitamin D Receptor Genetic Variants among CKD Patients of South Indian Population
}

\author{
Selvaraman Nagamani ${ }^{1}$, Shanmuga Perumal $\mathbf{M}^{2,3}$, Ankit Srivastava ${ }^{4}$, kh. Dhanachandra Singh ${ }^{1}$, Ritushree Kukreti ${ }^{4}$ and Karthikeyan \\ Muthusamy $^{1 *}$ \\ ${ }^{1}$ Department of Bioinformatics, Alagappa University, Karaikudi, Tamilnadu, India \\ ${ }^{2}$ Departments of Nephrology, Government Rajaji Hospital, Madurai, Tamilnadu, India \\ ${ }^{3}$ Lee Kidney Care \& Dialysis Centre, 5-Vanamamalai Nagar, Madurai, Tamilnadu, India \\ ${ }^{4}$ Genomics and Molecular Medicine Unit, Institute of Genomics and Integrative Biology (IGIB), Council of Scientific and Industrial Research (CSIR), Delhi, India
}

\begin{abstract}
Background and Objectives: Vitamin D Receptor (VDR) gene polymorphism has long been known for its association with Chronic Kidney Disease (CKD). We aimed to investigate the potential role of VDR gene polymorphisms in CKD patients.

Design and Methods: The association of VDR gene polymorphisms in CKD patients $(N=147$; males $=100$ $(68.03 \%)$ and females $=47(31.97 \%))$ is investigated in this study. The patient samples were compared with healthy control subjects ( $\mathrm{N}=210$; males: $130(61.90 \%)$ and females: $80(38.10 \%))$. Genotyping was carried out by polymerase chain reaction-restriction fragment length polymorphism method (PCR_RFLP). All the statistical analysis was carried out using the SPSS and PLINK-software.

Results: A significant difference in the genotype frequency of Apal-“CC" ( $p=0.015, \mathrm{OR}=0.51,95 \% \mathrm{Cl}=0.29$ 0.91 ) was observed in the patients vs. control subjects. Further, we observed that individuals with a/T haplotype were at a risk (0.25-fold higher; $95 \% \mathrm{Cl}=0.09-0.67)$. The serum calcium levels were increase in the patients with Apal $(A C+C C)$ variants, but were significantly decreased in the $A A$ variant $(9.6 \pm 1.16 \mathrm{vs} .9 .07 \pm 0.85 \mathrm{mg} / \mathrm{dL}, \mathrm{p}=0.0005)$. The serum $\mathrm{Hb}$ levels were also increase in the patients with Taql (TT) variants, but were significantly decreased in the $(\mathrm{TC}+\mathrm{CC})$ variants $(8.36 \pm 2.41 \mathrm{vs} .7 .86 \pm 2.20 \mathrm{mg} / \mathrm{dL}, \mathrm{p}=0.03)$. We also observed that the "AC" genotype of the Apal polymorphism when present in a combination with the "TC" genotype of Taql polymorphism conferred a 1.4 times higher risk (38/54) for developing CKD using MDR analysis.
\end{abstract}

Interpretations and Conclusions: Apal gene polymorphism of the VDR gene is significantly associated with CKD patients and the Apal "CC" variant could be a risk allele for CKD patients in South Indian population.

Keywords: Chronic kidney disease; Vitamin D receptor; SNP; Haplotypes

\section{Introduction}

Chronic Kidney Disease (CKD) is a progressive condition characterized by a decrease in the Glomerular Filtration Rate (GFR) over time which is less than $60 \mathrm{~mL} / \mathrm{min} / 1.73 \mathrm{~m}^{2}$ for duration of 3 months or longer and can even progress to End Stage Renal Disease (ESRD) [1]. The pathogenesis of CKD is due to a combination of multiple genetic and environmental factors leading to ESRD [2-4]. It results from a profound hydroelectrolytical, metabolic and immunobiological imbalance and is associated with a number of systemic complications [5]. Gene polymorphism has reported as an important factor to increase the susceptibility of CKD. In the past decades, many epidemiologic studies have been conducted to understand the relationship between VDR polymorphism and CKD risk [6-8]. In several studies, an inverse relationship has been observed between the bone mineral density and renal function [9-13].

The active vitamin $\mathrm{D}\left(1,25(\mathrm{OH})_{2} \mathrm{D}_{3}\right)$ is a steroid hormone which is metabolized in the liver and in the kidney. The active vitamin $\mathrm{D}$ interacted with its target nuclear receptor and exerts a wide variety of biological processes such as bone metabolism, immune response modulation, and regulation of cell proliferation and differentiation [14]. Further, VDR is also responsible for both positive and negative control of a few genes at the transcription level via VDR interaction [15].

The human VDR is located on chromosome 12 at $12 q 13-14$ [16]. The VDR gene contains 11 exons along with introns, spanning approximately $75 \mathrm{~kb}$ [17]. Approximately 100 polymorphisms are expected in the VDR region based on the Genome wide association study [18]. Polymorphisms are referred to as the presence of two or more alleles at a given locus, and if such alleles occur at a frequency of more than $1 \%$ in a population, the locus is known to be polymorphic. These polymorphisms are associated with several pathological conditions such as breast cancer [19], bone mass, bone turnover, bone mineral loss [20], osteoarthritis [21], and osteoporosis [22].

CKD has a gentic basis which combines interaction effects basically sequence variation of multiple genes with environment [23]. Vitamin D has played a major role among CKD patients as the bone metabolism modulator and it should be well balanced to avoid damage. The main aim of the present study is to evaluate the association of VDR polymorphisms and CKD. In this case-control study, we examined the possible associations between VDR gene polymorphisms in the South

*Corresponding author: Karthikeyan Muthusamy, Department of Bioinformatics, Alagappa University, Karaikudi, Tamilnadu, India, E-mail: mkbioinformatics@gmail.com

Received October 09, 2018; Accepted November 19, 2018; Published November 26, 2018

Citation: Nagamani S, Shanmuga Perumal M, Srivastava A, Dhanachandra Singh KH, Kukreti R (2018) Vitamin D Receptor Genetic Variants among CKD Patients of South Indian Population. J Clin Med Genomics 6: 152. doi: 10.4172/2472128X.1000152

Copyright: ( 2018 Nagamani S, et al. This is an open-access article distributed under the terms of the Creative Commons Attribution License, which permits unrestricted use, distribution, and reproduction in any medium, provided the original author and source are credited. 
Indian CKD population between the age group of 30 and 70 years. We determined the genotypes and haplotype association of ApaI and TaqI alleles of VDR in the study population.

\section{Subjects and Methods}

\section{Study population}

The work was carried out with the approval of the Institutional Ethical Committee. The patients were on regular follow-up in Lee kidney care hospital. Individuals with matched sex, and location were selected as the controls. All the participants belonged to the Dravidian ancestry of Tamilnadu population in South India. The inclusion criteria for patients selection were constantly elevated serum creatinine level above normal range $(0.6 \mathrm{mg} / \mathrm{dL}-1.2 \mathrm{mg} / \mathrm{dL})$ and creatinine clearance $<60 \mathrm{~mL} / \mathrm{min} / 1.73 \mathrm{~m}^{2}$. The CKD type was confirmed by ultrasound and/or Computed Tomography (CT) scan of the kidneys. The newly enrolled patients were excluded from the study. Controls with the risk factors such as family history of hypertension, diabetes mellitus, and hyperlipidemia were excluded from the study. Both the cases and controls were from the state of Tamil Nadu.

\section{Blood collection, DNA extraction and Genotyping}

A total of $5 \mathrm{~mL}$ of blood samples were collected from CKD patients and healthy volunteers between the age group of 30 and 70 years from clinics after obtaining informed consent from the participants. All the cases included in this study are under CKD stages (II-V) as diagnosed and identified by a nephrologist. The clinical data and family history were recorded in the questionnaire for all the participants. All the patient samples were collected from the Lee Kidney Care hospital. Control samples were also collected from the volunteers living in the same place and origin. Genomic DNA was extracted using modified Miller et al., protocol [24] and it was quantified spectrochemically by $\mathrm{OD}_{260} / \mathrm{OD}_{280}$ ratio. Genotyping was performed with PCR-RFLP according to Vupputuri et al. [25].

\section{Statistical Analysis}

Power and sample size calculations were conducted using genetic power test to estimate the Power of the study. Chi-square statistics was computed to compare the VDR genotype frequencies between the case and the control subjects. The strength of the association between the genotype frequencies was calculated by the Odds Ratio (OR) and the 95\% Confidence Interval (CI). $P$ value $<0.05$ was considered as a level of statistical significance for this study. Departure of Hardy-Weinberg Equilibrium (HWE) was tested for the frequencies of the marker alleles by the gene counting method. All the statistical calculations were carried out using PLINK 1.07 [26] and SPSS [27].

\section{Genetic power test}

We estimated the genetic power using the ApaI polymorphism as an example; an $80 \%$ power is required to detect the linkage between CKD and the "a" allele at a type "I" error of 0.05 when the sample includes 147 cases and 210 control subjects. Further, we performed post hoc exploratory analyses to examine the relationships of the polymorphisms with the case and control subjects.

\section{Results}

Among the patients $(\mathrm{n}=147), 100(68.03 \%)$ are male and 47 $(31.97 \%)$ are female, whereas in the control subjects $130(61.90 \%)$ are male and $81(38.10 \%)$ are female. The mean age of the patients is $53.9 \pm$ 12.3 years for male patients and $54.40 \pm 10.42$ years for female patients.
The mean age of the control subjects $(n=210)$ is $43.71 \pm 14.17$ years and $43.90 \pm 13.57$, respectively, for males and females. Genetic power estimation showed that 147 cases and 210 controls had $>80 \%$ power to detect the linkage between the ApaI variant and CKD in South Indian population.

\section{Distribution of VDR genotypes}

The genotype distributions of ApaI and TaqI polymorphisms were compatible with the HWE expectation in control subjects. The genotype, allele frequencies, and odds ratio were calculated for the variants to test the association of ApaI and TaqI polymorphisms with CKD patients. The "CC" and "AA" genotype of ApaI in the patients group was $13.61 \%$ and $32.65 \%$. Among controls it was $23.33 \%$ and $31.42 \%$, respectively, and both the groups (cases and controls) differed significantly $(p=0.015$; $\mathrm{OR}=0.51,95 \% \mathrm{CI}=0.29-0.91)$. In the case of TaqI, the "TT" genotype was present in $32.65 \%$, while "CC" was observed only in $16.65 \%$; compared to the control subjects ( $\mathrm{TT}=41.90 \%$; $\mathrm{CC}=16.19 \%$ ), it was not significantly associated with CKD $(p=1.00)$ after applying bonferroni corrections (Table 1).

\section{Combined analysis and haplotype distribution}

The genotypes of VDR genes were combined and compared in both the groups in order to evaluate the synergistic effect. The heterozygous and mutant types were combined together and compared with the wild type. The combined genotypes showed a significant difference in the frequency distribution of patients and control subjects (Table 2). In the double gene combination, we could not find significant changes.

\begin{tabular}{|c|c|c|c|c|}
\hline Genotype & $\begin{array}{c}\text { Patients, } \\
\text { n=147 (\%) }\end{array}$ & $\begin{array}{c}\text { Control, } \\
\mathrm{n}=210(\%)\end{array}$ & $\begin{array}{c}p- \\
\text { value }\end{array}$ & $\mathrm{OR}(95 \% \mathrm{Cl})$ \\
\hline \multicolumn{5}{|c|}{ Apal (db SNP ID rs 7975232) polymorphism } \\
\hline AA & $48(32.65)$ & $66(31.42)$ & 0.44 & $1.06(0.67-1.66)$ \\
\hline$A C$ & $79(53.74)$ & $95(45.24)$ & 0.07 & $1.41(0.92-2.15)$ \\
\hline $\mathrm{CC}$ & $20(13.61)$ & $49(23.33)$ & $0.015^{*}$ & $0.51(0.29-0.91)$ \\
\hline \multicolumn{5}{|l|}{ Allele frequency } \\
\hline Allele A & $175(59.52)$ & $227(54.05)$ & \multirow[b]{2}{*}{0.085} & \multirow[b]{2}{*}{$1.25(0.92-1.69)$} \\
\hline Allele C & $119(40.47)$ & 193 (45.95) & & \\
\hline \multicolumn{3}{|c|}{ Allele carriage frequency } & & \\
\hline A allele carriage & $127(86.39)$ & $161(76.67)$ & $0.015^{*}$ & $1.93(1.09-3.42)$ \\
\hline C allele carriage & $99(67.35)$ & $144(68.57)$ & 0.45 & $0.95(0.60-1.48)$ \\
\hline \multicolumn{5}{|c|}{ TaqI (db SNP ID rs 731236) polymorphism } \\
\hline TT & $48(32.65)$ & $88(41.90)$ & 0.05 & $0.67(0.43-1.04)$ \\
\hline TC & $76(51.70)$ & $88(41.90)$ & 0.045 & $1.48(0.97-2.27)$ \\
\hline $\mathrm{CC}$ & $23(16.65)$ & $34(16.19)$ & 0.50 & $0.96(0.54-1.71)$ \\
\hline \multicolumn{5}{|l|}{ Allele frequency } \\
\hline Allele T & $176(59.86)$ & $264(62.86)$ & \multirow[b]{2}{*}{0.17} & \multirow[b]{2}{*}{$0.85(0.63-1.16)$} \\
\hline Allele C & $122(41.49)$ & $156(37.14)$ & & \\
\hline \multicolumn{5}{|l|}{ Allele carriage frequency } \\
\hline T allele carriage & $124(84.35)$ & $176(83.81)$ & 0.50 & $1.04(0.73-0.58)$ \\
\hline C allele carriage & $99(67.35)$ & $122(58.10)$ & 0.045 & $1.49(0.96-2.31)$ \\
\hline \multicolumn{5}{|l|}{ SNP, Model \& Test } \\
\hline \begin{tabular}{|l|l|l|} 
Apal & $\mathrm{CC}+\mathrm{AC}$ Vs AA & $\mathrm{DOM}$ \\
\end{tabular} & $99 / 48$ & $144 / 66$ & 0.445 & $0.95(0.60-1.48)$ \\
\hline CC Vs AC + AA REC & $20 / 127$ & $49 / 161$ & 0.015 & $0.52(0.29-0.91)$ \\
\hline Taql CC + TC Vs TT DOM & $99 / 48$ & $122 / 88$ & 0.05 & $1.49(0.96-2.31)$ \\
\hline \begin{tabular}{l|l|l|} 
& CC Vs TC + TT & REC \\
\end{tabular} & $23 / 124$ & $34 / 176$ & 0.50 & $1.04(0.58-1.85)$ \\
\hline
\end{tabular}

Note: a-Chi-squared test. DOM: Dominant Model; REC: Recessive Model; $n$ : Sample Size; OR: Odds Ratio; $\mathrm{Cl}$ : Confidence Interval; * $\mathrm{p}<0.025$ statistically significant; After bonferrroni correction the significance threshold is $(0.05 / 2=0.025)$.

Table 1: Distribution of VDR polymorphism among CKD patients and healthy control group. 


\begin{tabular}{|l|c|c|c|c|}
\hline Genotype $^{\mathbf{a}}$ & $\begin{array}{c}\text { Patients, } \mathbf{n = 1 4 7} \\
\mathbf{( \% )}\end{array}$ & $\begin{array}{c}\text { Controls, } \\
\mathbf{n = 2 1 0}(\mathbf{\%})\end{array}$ & $\begin{array}{c}\text { Corrected } \\
\boldsymbol{p}-\text { value }^{\mathbf{a}}\end{array}$ & OR (95\% Cl) \\
\hline Taql and Apal \\
\hline T1 and A1 & $10(6.80)$ & $21(10)$ & 0.19 & $0.66(0.30-1.44)$ \\
\hline T1 and A0 & $38(25.85)$ & $67(31.90)$ & 0.13 & $0.74(0.47-1.19)$ \\
\hline T0 and A1 & $38(25.85)$ & $45(30.61)$ & 0.20 & $1.28(0.78-2.10)$ \\
\hline T0 and A0 & $61(41.50)$ & $77(36.67)$ & 0.21 & $1.23(0.80-1.89)$ \\
\hline
\end{tabular}

Note: a-Chi-sqaured test; 'Significance value $(p<0.05)$; $0=$ mutant+heterozygous $1=$ wild type genotype; ${ }^{a}$ After bonferrroni correction the significance threshold is $(0.05 / 2=0.025)$.

Table 2: Combined analysis of VDR genotypes among CKD patients and controls.

\begin{tabular}{|l|c|c|c|c|}
\hline Haplotype $^{\mathbf{a}}$ & $\begin{array}{c}\text { Patients, } \\
\mathbf{n = 1 4 7}(\mathbf{\%})\end{array}$ & $\begin{array}{c}\text { Controls, } \\
\mathbf{n = 2 1 0}(\mathbf{\%})\end{array}$ & $\boldsymbol{p}$ - value & OR (95\% CI) \\
\hline $\mathrm{A} / \mathrm{t}$ & $13(8.84)$ & $16(7.62)$ & 0.41 & $1.18(0.55-2.53)$ \\
\hline $\mathrm{a} / \mathrm{T}$ & $5(3.40)$ & $26(12.38)$ & $0.0025^{*}$ & $0.25(0.09-0.67)$ \\
\hline $\mathrm{A} / \mathrm{T}$ & $10(6.80)$ & $21(10)$ & 0.18 & $0.66(0.30-1.44)$ \\
\hline $\mathrm{a} / \mathrm{t}$ & $9(6.12)$ & $5(2.38)$ & 0.065 & $2.67(0.88-8.15)$ \\
\hline
\end{tabular}

Notes: a-Chi-sqaured test; For Apal, the haplotypes are "A" (wild type) and "a" (mutant type); for Taql the haplotypes are "T" (wild type) and "t" (mutant types); ${ }^{a}$ After bonferrroni correction the significance threshold is $(0.05 / 2=0.025)$.

Table 3: Haplotype distribution of $A p a l$ and Taql gene polymorphisms among CKD patients and controls.

Haplotype analysis revealed that "a/T" haplotype is comparatively lower in the patients $(3.40 \%)$ compared with controls $(12.38 \%)$ and the difference was statistically significant $(p=0.0025$; OR $=0.25 ; 95 \%$ $\mathrm{CI}=0.09-0.67)$ (Table 3). The plasma levels (mean $\pm \mathrm{SD}$ ) of creatinine, Glucose, calcium, $\mathrm{Hb}$ in $\mathrm{CKD}$ patients were compared with VDR genotypes. The serum calcium levels were increase in the patients with ApaI (AC+CC) variants, but were significantly decreased in the AA variant $(9.6 \pm 1.16$ vs. $9.07 \pm 0.85 \mathrm{mg} / \mathrm{dL}, \mathrm{p}=0.0005)$. In case of $\mathrm{Hb}$ levels we could observe the changes in TaqI polymorphism. The serum $\mathrm{Hb}$ levels were increase in the patients with TaqI (TT) variants, but were significantly decreased in the (TC+CC) variants $(8.36 \pm 2.41 v s .7 .86 \pm$ $2.20 \mathrm{mg} / \mathrm{dL}, \mathrm{p}=0.03)($ Table 4$)$.

\begin{tabular}{|c|c|c|c|}
\hline Characteristic & Genotype (W) & Genotype (H+M) & $p$-value ${ }^{a}$ \\
\hline Apal & $\mathrm{AA}(\mathrm{n}=48)$ & $A C+C C(n=79+20)$ & \\
\hline $\mathrm{Hb}$ & $8.44 \pm 2.39$ & $7.80 \pm 2.20$ & 0.091 \\
\hline S. Creatinine $\mathrm{mg} / \mathrm{dL}$ ) & $5.2 \pm 3.12$ & $4.93 \pm 3.13$ & 0.47 \\
\hline S. Glucose (mg/dL) & $115.97 \pm 50.14$ & $130.20 \pm 75.88$ & 0.051 \\
\hline S. Uric (mcmol/L) & $105.94 \pm 59.18$ & $116.12 \pm 83.06$ & 0.343 \\
\hline S. $\mathrm{Na}(\mathrm{mmol} / \mathrm{L})$ & $119.26 \pm 23.46$ & $123.89 \pm 12.77$ & 0.064 \\
\hline S. $\mathrm{K}(\mathrm{mmol} / \mathrm{L})$ & $4.86 \pm 1.82$ & $5.37 \pm 9.39$ & 0.3795 \\
\hline S. $\mathrm{Cl}(\mathrm{mmol} / \mathrm{L})$ & $92.03 \pm 23.62$ & $86.68 \pm 12.78$ & 0.0905 \\
\hline S. Ca (mg/dL) & $9.07 \pm 0.85$ & $9.6 \pm 1.16$ & $0.0005^{*}$ \\
\hline Taql & $\mathrm{TT}(\mathrm{n}=48)$ & $T C+C C(n=76+23)$ & \\
\hline $\mathrm{Hb}$ & $8.36 \pm 2.41$ & $7.86 \pm 2.20$ & 0.035 \\
\hline S. Creatinine $(\mathrm{mg} / \mathrm{dL})$ & $5.02 \pm 3.48$ & $5.02 \pm 2.97$ & 0.4865 \\
\hline S. Glucose (mg/dL) & $121.74 \pm 69.79$ & $125.65 \pm 68.44$ & 0.2755 \\
\hline S. Uric (mcmol/L) & $110.57 \pm 81.47$ & $113.35 \pm 73.67$ & 0.327 \\
\hline S. $\mathrm{Na}(\mathrm{mmol} / \mathrm{L})$ & 122. $04 \pm 16.11$ & $122.74 \pm 17.59$ & 0.3735 \\
\hline S. K (mmol/L) & $4.35 \pm 1.50$ & $4.86 \pm 1.45$ & 0.1935 \\
\hline S. $\mathrm{Cl}(\mathrm{mmol} / \mathrm{L})$ & $90.82 \pm 26.51$ & $86.11 \pm 20.85$ & 0.193 \\
\hline S. Ca (mg/dL) & $9.2 \pm 1.14$ & $9.2 \pm 1.18$ & 0.256 \\
\hline
\end{tabular}

The values are represented as mean \pm standard deviation. ${ }^{a}$ After bonferrroni correction the significance threshold is $(0.05 / 2=0.025)$.

Table 4: Biochemical parameter of patients $(n=147)$ with VDR gene polymorphisms.

\section{Analysis of Epistatic Interaction}

MDR (Multi Drug Resistence) analysis was applied to detect the gene-gene interactions in the cases and controls in order to elaborate the findings of the analysis. Table 5 summarizes the results of the MDR analysis evaluated for the two possible combinations of polymorphisms studied on the risk of developing CKD. It exhibits the best model with a combination of polymorphisms in order along with its prediction error and Coefficient of Variation (CV) consistency (Table 5). The results reveal that the interaction of the ApaI-TaqI polymorphisms is the best model with the least prediction error of 0.39 and a CV consistency $10 / 10$. For the present data, we set the threshold value of $1.0(210 / 210)$, which determines the high-risk (dark gray) and low-risk (light gray) genotypic combinations. It was also observed that the "AC" genotype of the ApaI polymorphism when present in a combination with the "TC" genotype of TaqI polymorphism conferred a 1.4 times higher risk (38/54) for developing CKD (Figure 1).

\section{Discussion}

CKD is associated with major osteoporosis complications [28]. It affects the older population ( $>50$ years) [29], therefore the mean age for male CKD patients is $53.90 \pm 12.33$ and for females it is $54.40 \pm 10.42$ in our study population. VDR acts as the bridging factor between CKD and osteoporosis $[29,30]$. The VDR gene comprises three components viz. 5 ' promoter (form exon la to f), coding exons (exon 2-9), and a 3 untranslated region in chromosome 12q13.1 [31]. Morrison et al. (1994) were the first to report that the VDR gene polymorphisms (BsmI, ApaI, and TaqI) were related to the Bone Mineral Density (BMD) [32]. Thus,

\begin{tabular}{|c|c|c|c|c|}
\hline Model & $\begin{array}{c}\text { Training bal. } \\
\text { acc. (\%) }\end{array}$ & $\begin{array}{c}\text { Testing bal. } \\
\text { acc. (\%) }\end{array}$ & $\begin{array}{c}\text { Cross- } \\
\text { validation } \\
\text { consistency }\end{array}$ & $\begin{array}{c}\text { Prediction } \\
\text { error }\end{array}$ \\
\hline Taql & 0.570 & 0.530 & $8 / 10$ & 0.430 \\
\hline Apal and Taql & 0.606 & 0.547 & $10 / 10$ & 0.394 \\
\hline
\end{tabular}

Table 5: Summary of MDR analysis. MDR analysis revealed that combination of Apal and Taql could be a high risk for the prevalence of CKD.

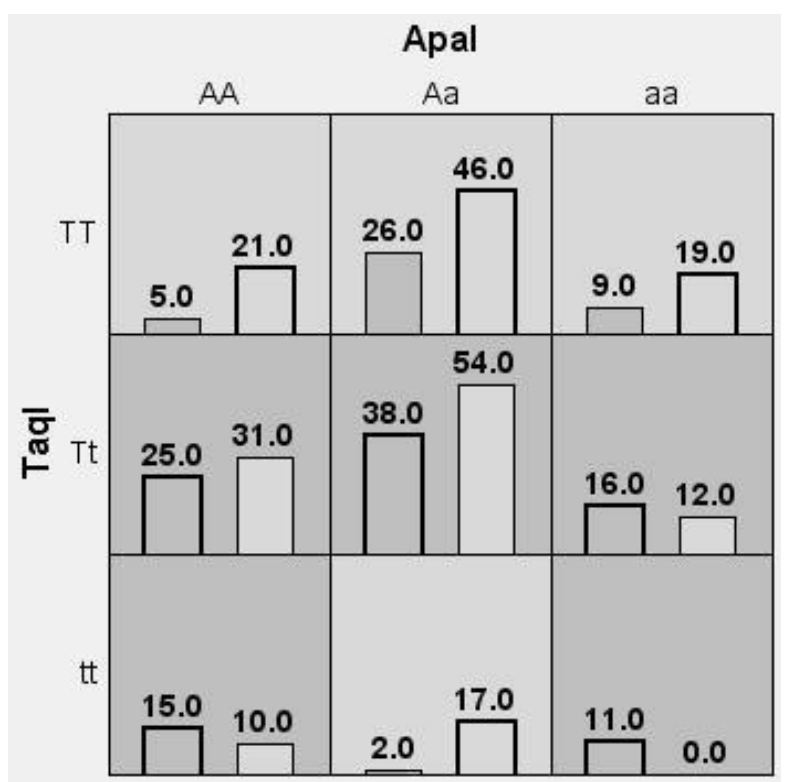

Figure 1: Distribution of high-risk (dark shaded) and low risk (light shaded) genotype among the markers studied. 
VDR gene polymorphisms are considered as important markers for osteoporosis [33]. The main objective of the present study is to evaluate the association of VDR gene polymorphism in CKD. The VDR gene polymorphism has been investigated in different malignancies among the Indian population [34-36].

The frequency of the minor allele of ApaI variant was 0.40 for this study among cases and this frequency were similar for different populations in 1000 Genome project, 0.36 in African, 0.55 in American, 0.46 in European and 0.41 in South Asian. Similarly, for the TaqI variant, the minor allele frequency was 0.41 and it is correlated with European (0.60) and South Asian (0.63) populations.

The VDR genotype differentiation may trigger a breakdown of the cytokine relationship directly or indirectly, and thus it may be associated with CKD pathogenesis, or it may cause the VDR structure alteration and ultimately lead to an altered receptor function that may increase or decrease the VDR expression and thereby cause disease [37]. Although the ApaI polymorphisms lie in the intronic region, they may influence the VDR expression, which includes the disruption of a splice site for the VDR mRNA transcription. This may result in the truncated or alternatively spliced protein product [38] or it may alter the mRNA product [14]. However, we could not observe any significant changes in the TaqI polymorphism. The TaqI polymorphism may cause a silent mutation in exon 9 with both ATT and ATC coding for isoleucine [39]. Thus, it may not affect the mRNA transcripts. Such types of associations have been reported in ESRD [40] and type 2 diabetes patients [41] from north India.

Further, we performed haplotype analysis. A single gene contained multiple polymorphisms. Moreover, for multiple polymorphisms within the same gene, information contained at each polymorphic site is "linked" to its neighbors. Therefore, inheriting one polymorphism means a high likelihood of inheriting the neighboring polymorphism [42]. Rather than a single SNP analysis, a haplotype analysis provides more information and it has an advantage in disease association studies, since it gives the cumulative effect of SNPs in that gene [43]. The haplotype analysis revealed that individuals with "a/T" haplotype had a higher risk.

VDR polymorphisms have been reported to modify the parathyroid cell differentiation and function. Wide variations have been observed in the degree of secondary hyperparathyroidism. Some patients develop severe and uncontrolled hyperparathyroidism, while others develop moderate elevated levels of iPTH levels which may fail to promote sufficient bone turnover and finally result in a dynamic bone disease [44]. However, it is not well defined the reason behind the heterogeneity in the clinical behavior. The serum calcium levels were significantly higher $(\mathrm{p}=0.0005)$ in the "CC" genotype of ApaI, showing correlation, which may act as a secondary check to the severity of secondary hyperparathyroidism.

Tripathi et al. studied and reported that ApaI, FokI, and BsmI VDR polymorphism may be one of the genetic risk factors for End Stage Renal Disease (ESRD) in north Indian population. They also observed that the genotype of frequency of ApaI (a) (C in our case), FokI (f), and BsmI (B) was significantly different among patients and controls. In our case, we could also observe ApaI (C) genotype frequency was significantly differ among patients and controls in south Indian population. In both the studies, there is no significant difference in case of $\mathrm{C}$ at TaqI restriction site. Moreover, they observed that the serum calcium levels were significantly higher $(p=0.001)$ in the BB genotype and in our study, we observed that serum calcium levels were significantly higher $(p=0.0005)$ in the AA genotype. Both the studies clearly indicated that serum calcium level play an important role among kidney disease populations in India.

Our study has a few limitations.

- The study was conducted with a low sample size

- We included only one kidney center in our study

- Controls were not age matched with the patients

More CKD patients from different kidney centers can be included for better interpretation of the role of VDR polymorphism or the progression of CKD. Moreover, there are no measurements are available to calculate the VDR levels in order to correlate with the VDR polymorphisms in this study. However, the samples are from a homogeneous genetic background, therefore, they may not be affected by the unmeasured confounding factors of population stratification.

In conclusion, we observed that VDR gene polymorphisms appear to be important genetic determinants associated with CKD patients. We observed that the "CC" of ApaI were strongly associated with CKD patients among the Tamil Nadu population. We could not find a significant association with the TaqI polymorphism among CKD patients.

\section{Declaration of Interest}

On behalf of all authors, the corresponding author states that there is no conflict of interest.

\section{References}

1. Quigley R (2012) Chronic kidney disease: Highlights for the general pediatrician. Int J Pediatr 1-5.

2. Adler S (2006) Renal disease: Environment, race, or genes? Ethn Dis 16: S235-39.

3. Boger CA, Heid IM (2011) Chronic kidney disease: Novel insights from genomewide association studies. Kidney Blood Press Res 34: 225-234.

4. Dwivedi RS, Herman JG, McCaffrey TA, Raj DS (2011) Beyond genetics: Epigenetic code in chronic kidney disease. Kidney Int 79: 23-32.

5. Proctor R, Kumar N, Stein A, Moles D, Porter S (2005) Oral and dental aspects of chronic renal failure. J Dent Res 84: 199-208.

6. Zhou TB, Jiang ZP, Huang MF (2014) Association of vitamin D receptor Bsm (rs1544410) gene polymorphism with the chronic kidney disease susceptibility J Recept Sig Transduct Res 34: 54-57.

7. Wang LY, Zhang P, Wang HF, Qin ZW, Wei KB, et al. (2016) Association of vitamin $D$ receptor gene polymorphisms with end-stage renal disease and the development of high-turnover renal osteodystrophy in a Chinese population Genet Mol Res 15: gmr15026825

8. Waziri B, Dix-Peek T, Dickens C, Duarte R, Naicker S (2018) Influence of vitamin $D$ receptor polymorphisms on biochemical markers of mineral bone disorders in South African patients with chronic kidney disease. BMC Nephrol 19: 30 .

9. Yendt ER, Cohanim M, Jarzylo S, Jones G, Rosenberg G (1991) Bone mass is related to creatinine clearance in normal elderly women. $J$ Bone Miner Res 6: 1043-1050.

10. Stein MS, Packham DK, Ebeling PR, Wark JD, Becker GJ (1996) Prevalence and risk factors for osteopenia in dialysis patients. Am J Kidney Dis 28: 515522

11. Rix M, Andreassen H, Eskildsen P, Langdahl B, Olgaard K (1999) Bone minera density and biochemical markers of bone turnover in patients with predialysis chronic renal failure. Kidney Int 56: 1084-1093.

12. Lobão R, Carvalho AB, Cuppari L, Ventura R, Lazaretti-Castro M, et al. (2004) High prevalence of low bone mineral density in pre-dialysis chronic kidney disease patients: Bone histomorphometric analysis. Clin Nephrol 62: 432-439. 
Citation: Nagamani S, Shanmuga Perumal M, Srivastava A, Dhanachandra Singh KH, Kukreti R (2018) Vitamin D Receptor Genetic Variants among CKD Patients of South Indian Population. J Clin Med Genomics 6: 152. doi: 10.4172/2472-128X.1000152

Page 5 of 5

13. Avila M, Prado C, Ventura MD, Mora C, Briones D, et al. (2010) Vitamin D receptor gene, biochemical bone markers and bone mineral density in Mexican women on dialysis. Nephrol Dial Transplant 25: 2259-2265.

14. Holick MF (2004) Vitamin D: Importance in the prevention of cancers, type 1 diabetes, heart disease, and osteoporosis. Am J Clin Nutr 79: 362-371.

15. Sutton AL, MacDonald PN (2003) Vitamin D: More than a "bone-a-fide" hormone. Mol Endocrinol 17: 777-791.

16. Labuda M, Fujiwara TM, Ross MV, Morgan K, Garcia-Heras J, et al. (1992) Two hereditary defects related to vitamin $\mathrm{D}$ metabolism map to the same region of human chromosome 12q13-14. J Bone Miner Res 7: 1447-1453.

17. Miyamoto K, Kesterson RA, Yamamoto H, Taketani Y, Nishiwaki E, et al. (1997) Structural organization of the human vitamin $D$ receptor chromosomal gene and its promoter. Mol Endocrinol 11: 1165-1179.

18. Uitterlinden AG, Fang Y, Bergink AP, van Meurs JB, van Leeuwen HP, et al. (2002) The role of vitamin $D$ receptor gene polymorphisms in bone biology. Mol Cell Endocrinol 197: 15-21.

19. Lundin AC, Soderkvist P, Eriksson B, Bergman-Jungestrom M, Wingren S (1999) Association of breast cancer progression with a vitamin D receptor gene polymorphism. South-East Sweden Breast Cancer Group. Cancer Res 59: 2332-2334.

20. Karkoszka H, Chudek J, Strzelczyk P, Wiecek A, Schmidt-Gayk H, et al. (1998) Vitamin $D$ receptor gene polymorphism and the rate of bone loss of the femur neck and lumbar spine in hemodialized patients with chronic renal failure. Pol Merkur Lekarski 5: 199-202.

21. Uitterlinden AG, Burger H, Huang Q, Odding E, Duijn CM, et al. (1997) Vitamin $D$ receptor genotype is associated with radiographic osteoarthritis at the knee. J Clin Invest 100: 259-263.

22. Sun JL, Meng HX, Cao CF, Tachi Y, Shinohara M, et al. (2002) Relationship between vitamin $\mathrm{D}$ receptor gene polymorphism and periodontitis. J Periodonta Res 37:263-267.

23. Rannala B (2001) Finding genes influencing susceptibility to complex diseases in the postgenome era. Am J Pharmacogenomics 1: 203-221.

24. Miller SA, Dykes DD, Polesky HF (1998) A simple salting out procedure for extracting DNA from human nucleated cells. Nucleic Acids Res 16: 1215.

25. Vupputuri MR, Goswami R, Gupta N, Ray D, Tandon N, et al. (2006) Prevalence and functional significance of 25-hydroxyvitamin $D$ deficiency and vitamin D receptor gene polymorphisms in Asian Indians. Am J Clin Nutr 83: 1411-1419.

26. Purcell S, Neale B, Todd-Brown K, Thomas L, Ferreira MA, et al. (2007) PLINK: A tool set for whole-genome association and population-based linkage analyses. Am J Hum Genet 81:559-575.

27. https://www.scirp.org/(S(vtj3fa45qm1ean45vvffcz55))/reference/ ReferencesPapers.aspx?ReferencelD=1311807
28. Miller PD (2015) Chronic kidney disease and osteoporosis: Evaluation and management. Bonekey Rep 3: 542.

29. Bartmanska M, Wiecek A (2016) Chronic kidney disease and the aging population. G Ital Nefrol 66: 33

30. Moldovan D, Rusu C, Kacso IM, Potra A, Patiu IM, et al. (2016) Mineral and bone disorders, morbidity and mortality in end-stage renal failure patients on chronic dialysis. Clujul Med 89: 94-103.

31. Choi SK, Park MS, Song JK, Yoon KS, Yoon KL, et al. (2013) Association of polymorphisms in the vitamin $\mathrm{D}$ receptor promoter with idiopathic short stature. J Korean Med Sci 28: 1329-1333.

32. Morrison NA, Qi JC, Tokita A, Kelly PJ, Crofts L, et al. (1994) Prediction of bone density from vitamin D receptor alleles. Nature 367: 284-287.

33. Kim SW, Lee JM, Ha JH, Kang HH, Rhee CK, et al. (2015) Association between vitamin $\mathrm{D}$ receptor polymorphisms and osteoporosis in patients with COPD. Int J Chron Obstruct Pulmon Dis 10: 1809-1817.

34. Vidyarani M, Selvaraj P, Raghavan S, Narayanan PR (2009) Regulatory role of 1, 25-dihydroxyvitamin D3 and vitamin D receptor gene variants on intracellula granzyme A expression in pulmonary tuberculosis. Exp Mol Pathol 86: 69-73.

35. Alagarasu K, Selvaraj P, Swaminathan S, Narendran G, Narayanan PR (2009) 5' regulatory and 3' untranslated region polymorphisms of vitamin $D$ receptor gene in south Indian HIV and HIV-TB patients. J Clin Immunol 29: 196-204.

36. Onsory K, Sobti RC, Al-Badran Al, Watanabe M, Shiraishi T, et al. (2008) Hormone receptor-related gene polymorphisms and prostate cancer risk in North Indian population. Mol Cell Biochem 314: 25-35.

37. Lagishetty V, Liu NQ, Hewison M (2011) Vitamin D metabolism and innate immunity. Mol Cell Endocrinol 347: 97-105.

38. Nesic D, Cheng J, Maquat LE (1993) Sequences within the last intron function in RNA 3'-end formation in cultured cells. Mol Cell Biol 13: 3359-3369.

39. Marco MP, Martinez I, Amoedo ML, Borras M, Saracho R, et al. (1999) Vitamin $D$ receptor genotype influences parathyroid hormone and calcitriol levels in predialysis patients. Kidney Int 56: 1349-1353.

40. Tripathi G, Sharma R, Sharma RK, Gupta SK, Sankhwar SN, et al. (2010) Vitamin $D$ receptor genetic variants among patients with end-stage renal disease. Ren Fail 32: 969-977.

41. Bid HK, Konwar R, Aggarwal CG, Gautam S, Saxena M, et al. (2009) Vitamin $\mathrm{D}$ receptor (Fokl, Bsml and Taql) gene polymorphisms and type 2 diabetes mellitus: A North Indian study. Indian J Med Sci 63: 187-194.

42. Thakkinstian A, D'Este C, Attia J (2004) Haplotype analysis of VDR gene polymorphisms: A meta-analysis. Osteoporos Int 15:729-734.

43. Singh M, Singh P, Singh S, Juneja PK, Kaur T (2013) Vitamin D receptor (VDR) gene polymorphism influences the risk of osteoporosis in postmenopausal women of Northwest India. Arch Osteoporos 8: 147.

44. Ott SM (2009) Bone density in patients with chronic kidney disease stages 4-5 Nephrology (Carlton) 14: 395-403. 